\title{
INOVATÍVNY PROFIL A ORIENTÁCIA NA INOVÁCIE. PRÍPADOVÁ ŠTÚdIA SLOVENSKO
}

INNOVATIVE PROFILE AND FOCUS ON INNOVATIONS. CASE STUDY SLOVAKIA

\author{
DOC. Mgr. Ing. Renáta JeŽKoVÁ, PhD. \\ Katedra ekonomiky a řizeni $\mid$ Department of economy and management \\ Akademie STING, o. p. s. STING Academy \\ $\bowtie$ Stromovka 1, 63700 Brno, Czech Republic \\ E-mail: renata.jezkova@post.sting.cz
}

\begin{abstract}
Anotácia
Príspevok analyzuje inovačný profil a orientácie Slovenska na inovácie. Cielom je odpovedat’ na otázku, na akej úrovni je inovačný profil SR z pohl'adu rôznych hodnotení v porovnani s krajinami EU 27, V4 a s krajinami v skupine (tzv. dobiehajúcich krajín) a aké by mali byt' opatrenia pre zlepšenie tohto stavu vbudúcnosti? Opreli sme sa o výsledky sekundárnych empirických výskumov publikovaných vo výskume GEM - Globálneho monitoru podnikania, publikovaného v roku 2012 $a v$ čiastkovej štúdii Inovácie a technologický transfer v SR, osobitne v SAV, ktorú publikovala SAV v rámci riešenia programu Centra excelentnosti SAV-CESTA. Slovensko je voblasti inovačnej výkonnosti hodnotené ako mierny inovátor, tzv. dobiehajúca krajina, a celkovo voblasti inovácii dosahuje neuspokojivé výsledky či už v porovnani s ostatnými krajinami EU 27, V4, s krajinami $v$ skupine, alebo vodcom v inováciách - Švajčiarskom. Tak počiatoční ako i etablovani podnikatelia na Slovensku vo všeobecnosti skôr inovácie pasívne prijímajú, než by mali snahu ich sami na trh aktívne prinášat'. Najhorším stavom a výrazným zaostávaním sa vyznačuje transfer vedy a výskumu na Slovensku. Je nevyhnutné, aby efektivnejšie fungoval systém vedy, čo predpokladá lepšie dotácie pre vedu a výskum, je potrebné ozdravit' grantový systém, zabraňovat' korupcii pri pridel'ovani vel'kých projektov najmä zo štrukturálnych fondov, fungovanie inovačného systému, etablovanie systému vzdelávania pre inovátorov a vychovávanie mladých l’udi na vysokých školách ku kreativite, inovatívnosti a väčšej podnikavosti.
\end{abstract}

\section{Kl'účové slová}

inovácie, Slovensko, GEM (Globálny monitor podnikania), hodnotenie inovatívnosti

\section{Annotation}

The paper analyses the innovative profile and focus of Slovakia on innovations. The goal is to answer a question: On what level is an innovative profile of the Slovak Republic from a point of view of different evaluations in comparison with the EU 27 countries, Visegrad countries and with the countries in the group and what should be measures to improve this state in a future? We came out from the results of secondary empirical researches published in GEM (Global Entrepreneurship Monitor) research published in 2012, and in the partial study Innovations and technology transfer in the Slovak Republic, especially in Slovak Academy of Science, published by the Slovak Academy of Science within solving the programme of The Excellence Centre of the Slovak Academy of Science. In a field of innovative performance Slovakia has been evaluated as a moderate innovator and generally in the field of innovations it has reached not satisfied results in comparison with other EU27 countries, Visegrad countries, the countries in the group or with the innovation leader Switzerland. In general, the entrepreneurs-beginners as well as starting up in Slovakia rather passively accept innovations than they themselves actively bring it to the market. There is the worst situation and significant lag in technology transfer in Slovakia. A system of the science should work more effectively, what supposes: better grants for research and development, it is necessary to restore a health of the grant system, inhibit a corruption by allocation of big projects mainly from the 
Structural funds, working of the innovation system, starting the system of education for innovators and education of young people at universities to be creative, innovative and enterprising.

Key words innovations, Slovakia, GEM (Global Entrepreneurship Monitor), evaluation of innovativeness

JEL classification: 031

\section{Úvod}

Inovácie môžeme v súčasnosti považovat’ za jeden z najvýznamnejších faktorov rozvoja spoločnosti. Sú jedným z hlavných faktorov, na ktorých je založená medzinárodná konkurencieschopnost' štátov a ich výkonnost', výstupy a zamestnanost'(Asheim, B.T., Isaksen, A. 1997; Michie, J. 1998).

Existuje široké spektrum názorov, čo možno rozumiet pod pojmom inovácia. Ako uvádzajú Luby a Chodák (2012, s. 4) vo svojej čiastkovej štúdii, „V súčasnosti existuje okolo 200 rozličných definícií inovácií“.

Zakladatel' teórie inovácií, Joseph Schumpeter, v roku 1912 formuloval tzv. „kombinácie vývojových zmien“ a v publikácii „Theorie der wirtschaftlichen Entwicklung“ zároveň postuloval pät' typických zmien (Keklik, M. 2003, Dvořák 2006): (1) používanie novej techniky, nových, t.j. v danom priemyselnom odvetví doposial prakticky neznámych výrobných metód, výrobných procesov a marketingového zabezpečenia výroby; (2) zavádzanie nových, pre spotrebitel’a doposial' neznámych výrobkov, resp. pôvodných výrobkov vyznačujúcich sa novými vlastnost'ami resp. novou kvalitou; (3) získavanie a používanie nových zdrojov surovín, materiálov alebo polotovarov bez ohl'adu na to, či tieto už predtým existovali; (4) zmeny v organizácii výroby, distribúcie a predaja, vedenie novej organizácie (napr. získanie monopolného postavenia alebo naopak, zrušenie monopolu); (5) prenikanie na nové trhy, zmena štruktúry trhu. Dnes už Schumpeterov názor zaznamenal posun, a síce že za inovácie sa považujú nielen absolútne novinky, ale i relatívne novinky, ktoré sú nové vzhl'adom na daný trh alebo výrobnú jednotku.

Pôvodná Schumpeterova teória bola neskôr rozpracovaná vel'kým množstvom autorov a dnes sa tieto práce zameriavajú predovšetkým na úspešné riadenie inovácií v podniku (pozri napr. Valenta, F. 1969 a 2001, Baumol, W.J. 2002, Rothwell, R., Gardiner 1985), pričom prevládajú definície chápajúce inováciu ako výsledok určitej aktivity s priamym ekonomickým efektom, a to napr. definícia inovácie podl'a OECD (2005), alebo zákona č. 172/2005 Z. z.

Avšak, za inovácie možno považovat’ aj činnosti, ktoré nemajú, alebo majú len nepriamy ekonomický účinok. Ide o inovácie $\mathrm{z}$ najširšieho uhla pohl'adu (vrátane tých v sociálnej sfére definované napr. Green Paper on Innovation vydaný EK v roku 2005). Ponúkajú nové riešenia problémov a tým umožňuje uspokojit' potreby jednotlivca a spoločnosti.

Pojem inovácia je jednoznačne spojený s existenciou konkrétneho výrobku, technologického postupu, nového organizačného usporiadania, ktoré boli úspešne aplikované v praxi, t.j. za inovácie je možné považovat' len výsledky vedeckých, výskumných a vývojových činností, ktoré sa dočkajú svojej realizácie.

Všeobecne platné faktory, ktoré brzdia inovačné snahy v regióne (Luby, Š., Chodák, I., s. 7):

(1) nejednotný a nejasný postup riadiacich orgánov najmä na najvyšších stupňoch, (2) nedostatočná a nevhodná legislatíva, (3) malá motivácia výskumníkov, (4) nedostatok kvalifikovaného personálu pre výkon transferu technológií, (5) slabá prepojenost' na regionálne, národné a medzinárodné zdroje, priemyselných partnerov a rizikový kapitál. 
$\mathrm{Na}$ zlepšenie tohto stavu odporúčajú uvedení autori vytvorit' následnú podporu kooperácie medzi priemyselnými podnikmi a univerzitami, zvýšenie kvality l'udských zdrojov v akademickom sektore a vo firmách, zvýšenie podnikatel'ského ducha a vytváranie MSP a zlepšenie manažmentu v oblasti transferu technológií s dôrazom na ochranu duševného vlastníctva.

Európska komisia predstavila v marci 2010 dokument Európa 2020, predstavujúci stratégiu rastu do roku 2020. Medzi jej priority patrí aj inteligentný rast na báze znalostí a inovácií, podporou ktorého má byt' $3 \%$ HDP vynaloženého na vedu a výskum ako ciel' pre všetky krajiny EU27. Zároveň bolo vytýčených 7 iniciatív typu vlajkovej lode, medzi ktorými nechýbala inovačná únia, inovácie pre rast a zamestnanost', zlepšenie rámca a prístupu ku kapitálu a priemyselná politika pre globalizačnú éru zlepšenie podnikatel'ského prostredia, najmä pre MSP.

V návrhu materiálu Inovačná politika na roky 2011 - 2013 v pôsobnosti Ministerstva hospodárstva SR, ktorý bol prerokovaný vo vláde SR 11.5.2011 (Ministerstvo hospodárstva 2011) sa konštatuje, že v dnešnej dobe sa verejné investície do vzdelávania, vedomostnej infraštruktúry, vedy a výskumu znižujú, čo bude mat' zásadný vplyv na rast inovácií v budúcnosti. Z krátkodobého hladiska má zníženie výdavkov v týchto oblastiach pozitívny vplyv na fiškálne výsledky, z dlhodobého hl'adiska to má negatívny vplyv na rast a konkurencieschopnost' ekonomiky ako takej. Hoci inovácie patria medzi vlajkové iniciatívy EU a ukazuje sa, že podpora inovačných aktivít v podnikoch, hlavne malých a stredných, je jedným zo základných nástrojov zabezpečenia rozvoja Slovenska, z Európskeho inovačného hodnotenia vyplýva, že Slovensko je až na 23. mieste spomedzi 27 krajín EU z hl'adiska inovačnej výkonnosti a patrí do skupiny tzv. dobiehajúcich krajín. Hospodársky rozvoj nemá byt' založený len na lacnej pracovnej sile, je nedostatok vel'kých podnikov, ktoré do výskumu investujú, ako neefektívna sa javí podpora zo strany verejného sektora a prevláda nízka motivácia výskumných pracovníkov.

\section{Ciel' a metódy}

Ciel'om príspevku je odpovedat' na otázku, na akej úrovni je inovačný profil SR z pohl'adu rôznych hodnotení v porovnaní s krajinami EU 27, V4 a s krajinami v skupine (tzv. dobiehajúcich krajín) a aké by mali byt' opatrenia pre zlepšenie tohto stavu v budúcnosti?

Pri skúmaní inovatívnej orientácie Slovenska vychádzame z výsledkov sekundárnych empirických výskumov - Global Entrepreneurship Research Association (GERA) - medzinárodného akademického výskumného združenia zastrešujúceho celosvetový Globálny monitor podnikania Global Entrepreneurship Monitor (d’alej len GEM), ktorého výstupom je najväššia svetová akademická štúdia $\mathrm{v}$ oblasti podnikania. Tá skúma úlohu podnikania $\mathrm{v}$ národnom ekonomickom raste prostredníctvom odhal'ovania čŕt a charakteristík podnikatel'skej aktivity jednotlivcov, ako aj ich postojov a ašpirácí́. Okrem toho tiež skúma aké je podnikatel’ské prostredie, ktoré jeho podmienky na národnej úrovni podporujú podnikanie, a ktoré by naopak, v záujme dosiahnutia ekonomického rastu krajiny, bolo potrebné posilnit'. Slovensko sa po prvýkrát zapojilo do GEM v roku 2011 a štúdia vyšla v roku 2012 (Pilková, A. a kol. 2012). Národným koordinátorom tohto projektu za Slovensko je Fakulta managementu Univerzity Komenského v Bratislave. Hlavným partnerom je Národná agentúra pre rozvoj malého a stredného podnikania. Ďalším kl'účovým zdrojom bola čiastková štúdia Inovácie a technologický transfer $\mathrm{v} S R$, osobitne $\mathrm{v} S A V$, ktorú publikovala $\mathrm{SAV}$ v rámci riešenia programu Centra excelentnosti SAV-CESTA. Použili sme metódy analýzy a syntézy.

\section{Výsledky}

Implementácia programu Európa 2020 sa hodnotila prostredníctvom Innovation Union Scoreboard 2010 (nástroj na komparatívne hodnotenie inovačnej výkonnosti členských krajín EÚ a d’alších vybraných krajín vrátane Švajčiarska), ktorá bola zverejnená v roku 2011. Analyzovala sa tu situácia v 27 členských štátoch EÚ a Chorvátska, Islandu, Macedónska, Nórska, Srbska, Švajčiarska a Turecka. Hodnotenie inovačnej výkonnosti pozostáva z 25 ukazovatel'ov, ktoré sú zoradené do 8 
inovačných dimenzií a troch hlavných skupín. Ide o ukazovatele, ktoré komplexne zachytávajú výkonnost' národných výskumných a inovačných systémov. V každom indikátore sa hodnotilo v rozmedzí od 0 ako najhorší po 1 ako najlepší. Slovensko sa v tomto hodnotení nachádzalo vel'mi nízko. Krajiny boli rozdelené podl'a priemeru hodnotenia do 4 skupín, a to inovační lídri $(0,7-0,75$ : Švédsko, Dánsko, Fínsko a Nemecko); inovační nasledovatelia $(0,47$ - 0,62: Vel'ká Británia, Belgicko, Rakúsko, Holandsko, Írsko, Luxembursko, Francúzsko, Cyprus, Slovinsko, Estónsko - tieto krajiny sú okolo priemeru EU27, t.j. 0,53); mierni inovátori (0,27 - 0,45: Portugalsko, Taliansko, ČR, Španielsko, Grécko, Malta, Mad’arsko, Pol'sko, Slovensko) a slabí inovátori (0,2 - 0,23: Rumunsko, Lotyšsko, Bulharsko, Litva.

Pri analyzovaní inovatívnej orientácie Slovenska d’alej vychádzame z Globálneho monitoru podnikania (d’alej len GEM) a z inovačného profilu podnikania tak, ako ho chápe Schumpeter. V jeho poňatí ide o kombinácie nových produktov a trhu, ktoré rušia zastarané produkty a služby a posúvajú tým produkčné hranice dopredu (Schumpeter, J. A. 1942). Výskum GEM skúma túto otázku cez dopytovanie sa o rozsahu, vakom produkt alebo služba, ktorú ponúka podnikatel' je nová pre niektorých alebo všetkých zákazníkov, a tiež či ešte niekto alebo naopak nikto neponúka tento istý produkt. Inovatívnymi podnikatel'mi sú teda takí, ktorých produkt alebo služba sú nové pre všetkých alebo aspoň pre niektorých zákazníkov, a ktorí majú len málo alebo žiadnych konkurentov v ponuke tohto produktu alebo služby. Druhým analyzovaným aspektom je inovatívnost' podnikatel'ov z hl'adiska využívania technológie.

Z výskumu GEM vyplýva, že celkovo je na Slovensku len 21,2 \% počiatočných podnikatel'ov, ktorých možno označit' za inovatívnych, teda majú produkt, ktorý ich zákazníci vnímajú ako nový, a súčasne nemajú vel'a konkurentov. Ak porovnáme inovatívnost' podnikatel'ov zahrnutých do počiatočnej podnikatel'skej aktivity s etablovanými podnikatel'mi, etablovaní podnikatelia sú inovatívni výrazne menej $(8,4 \%)$.

Ak porovnáme priemerné hodnoty podielu inovatívnych podnikatel'ov za rok 2011 a poradie Slovenska $v$ jednotlivých skupinách podl'a podielu inovatívnych podnikatel'ov v roku 2011, je zrejmá vel’mi zlá pozícia Slovenska, a to tak vo svete (37. resp. 44 miesto z 54 krajín), ako i v Európe (23. resp. 22. miesto z 26 krajín), v skupine krajín, ktorých rozvoj je založený na efektívnosti (16. resp. 18. miesto z 24 krajín), či v rámci krajín V4 (posledné miesto).

Čo sa týka druhého prístupu hodnotenia inovatívnosti, jeho predmetom bola analýza miery do akej používajú podnikatelia nové technológie.

Z analýzy vyplýva, že $57,4 \%$ počiatočných podnikatel'ov na Slovensku nepoužíva žiadne nové technológie, a zase $22,9 \%$ použiva najnovšie technológie, ktoré nie sú staršie ako 1 rok. V prípade etablovaných podnikatel'ov je tento podiel $73,5 \%$ resp. $11,9 \%$, z čoho jasne vyplýva, že etablovaných podnikatel'ov možno z hl'adiska využívanie najnovších technológií považovat' v tomto prípade za menej inovatívnych. Ak porovnáme inovatívnost počiatočných a etablovaných podnikatel'ov zhl'adiska využívania najnovších technológií, zistíme, že Slovensko dosahuje vel'mi dobré umiestnenie vo svete (4. resp. 5. miesto z 54 krajín), v Európe (1. resp. 3. miesto z 26 krajín), medzi krajinami, ktorých rozvoj je založený na efektívnosti (2. resp. 1. miesto z 24 krajín), ako i medzi krajinami V4 (1. resp. 2. miesto).

Ak sa pozrieme na d’alšie podmienky podnikania a porovnáme Slovensko s d'alšími 22 krajinami vo svojej skupine, najhoršie hodnotenie zaznamenávame v „záujme spotrebitel'ov o inovácie“ (19. miesto). Ak Slovensko porovnáme $\mathrm{v}$ hodnotení podmienok $\mathrm{s}$ najvyššie hodnotenou krajinou vo všetkých aspektoch podnikania - Švajčiarskom, najviac zaostáva v podmienke ,záujem podnikov o inovácie“" (rozdiel až -0,89 zo škály 1 najhoršie, 5 najlepšie).

Zo zhrnutia medzinárodného porovnania podmienok na podnikanie na Slovensku v porovnaní s krajinami EU, V4, Švajčiarska i svojej skupiny vyplýva, že najhorší stav vykazuje Slovensko i v „Transfere vedy a výskumu“ s hodnotením 1,87, pričom priemer v Európe je 2,38 a priemer 
v skupine je 2,18. V porovnaní s Európou je na poslednom, 23. mieste a v porovnaní s krajinami, ktorých rozvoj je založený na efektívnosti sa umiestnilo na predposlednom mieste. V porovnaní s krajinami V4 je na poslednom, 4. mieste. „Transfer vedy a výskumu“ je tak celkovo najhoršie hodnotenou podmienkou. Spomedzi krajín Európy je vhodnotení tejto podmienky najlepšie Švajčiarsko.

Na tomto mieste treba poznamenat', že legislatívne prostredie ohl'adne transferu vedy a výskumu sa postupne dotvára. Hoci Slovensko v roku 2002 pristúpilo k Európskemu patentovému dohovoru, počet prihlášok patentov je zatial', podl'a Lubyho a Chodáka (2012), malý (asi 200 ročne). Podl'a ich názoru by tomuto neutešenému stavu mala pomôct' aj niekol'konásobná novelizácia a zmeny v Zákone o vysokých školách, ktorý umožňuje verejným vysokým školám hospodárenie s majetkom tak, že za istých podmienok ho možno využit' na podnikatel'skú činnost' resp. na uzatvorenie zmluvy o združení, resp. prenajat' majetok za nižšie nájomné ako je obvyklé, čo má viest' $\mathrm{k}$ tesnejšej spolupráci vysokých škôl s priemyslom.

V rámci legislatívy o štátnej podpore výskumu a vývoja sú zadefinované centrá excelentnosti, vedecko-technologické parky, výskumno-vývojové centrá a technologické inkubátory a existujú i stimuly pre výskum a vývoj. Výsledkom sú prvé pozitívne, zatial však len ojedinelé príklady podnikania vo vede a výskume, a to zo Slovenskej technickej univerzity v Bratislave, Žilinskej univerzity v Žiline a Košice so snahou vybudovat' vedecko-technologický park.

Slovenská veda a výskum však stále trpia finančnou poddimenzovanost'ou zo strany štátu, čo dovol'uje zatial' len medzinárodnú sút'až v poznávacej rovine vedy a výskumu, ale neumožňuje dosiahnutie kritických hodnôt potrebných na presadenie inovácií. Avšak treba sa pozriet', na druhej strane i na to, aký je záujem zo strany MSP zavádzat' autentické inovácie kategórie vysokých technológií. Štátna pomoc na vedu a výskum čerpaná zo strany MSP je slabá (MF SR, 2009), v programe CIP EÚ s rozpočtom 3,6 mld Eur na roky 2007 - 2013 Slovensko zohráva pasívnu úlohu a tak isto možno hodnotit' i situáciu po prvých výzvach MH SR v ŠF. Odpoved’ou na otázku, kde vlastne inovujúce podniky sú, by mohla byt' i skutočnost', ako sa zmenil adresár vedeckovýskumných jednotiek na Slovensku z roku 1994 v porovnaní s vládnym materiálom č. 128 z februára 2008. Ako v o svojej čiastkovej výskumnej správe uvádzajú Luby a Chodák, „v roku 1994 sa k týmto inštitúciám hlásilo takmer 190 štátnych podnikov, a.s. a s.r.o. okrem SAV, vysokých škôl, múzeí, kultúrnych ustanovizní a Matice Slovenskej; naproti tomu v Inovačnej politike vlády sa v tejto kategórií nachádza už len 40 jednotiek“. Tieto inštitúcie hlásiace sa k vede a výskumu, navyše, pôsobia v málo stimulujúcom prostredí, vzhl’adom na výraznú závislost' medzi nákladmi práce a ochotou a schopnost'ou podnikov investovat' do vedy a výskumu. Ako títo autori dodávajú, krajiny s nízkymi mzdami konkurujú lacnou pracovnou silou, zatial' čo do inovácí́ investujú krajiny s vysokými mzdami.

Ak sa ešte vrátime k výsledkom „Transferu vedy a výskumu“ na Slovensku, najvyššie hodnotenie spomedzi jednotlivých dimenzií dosahuje dimenzia „Dostupnost' najnovších technológií pre nové firmy." Hoci má hodnotenie $(2,14)$ d’aleko od pozitívneho vnímania (hovoríme o ňom nad hodnotou 3), ide o pozitívne prekročenie priemerných hodnôt. Medzi krajinami Európy je Slovensko na 10. mieste a v skupine krajín na 2. mieste. Naopak, najhoršie hodnotenie spomedzi všetkých dimenzií zastáva dimenzia „Dotácie na získanie nových technológii“. V porovnaní s krajinami Európy a skupiny sa Slovensko nachádza na 21. mieste a ide celkovo o najnižšie hodnotenú dimenziu na Slovensku. Druhá najhoršia je dimenzia „Podpora nových technológií na svetovej úrovni““ (22. miesto v porovnaní s Európou a krajinami zo skupiny), čo vypovedá o vel'mi slabej efektivite podpory vedecko-technickej základne na vytváranie venture parkov založených na novej technológii na svetovej úrovni. Najvyššie hodnotenie „Transferu vedy a výskumu“ podla Innovation Union Scoreboard 2011 dosahuje Švajčiarsko, ktoré je považované vd’aka svojmu najvyššiemu hodnoteniu za inovačného lídra. V inovačnej výkonnosti ale aj v raste prekonáva všetky krajiny EÚ už 4. rok za sebou (Innovation Union Scoreboard 2011, s. 17). Toto postavenie zodpovedá aj d’alším zisteniam, a síce GCR (WEF), kde Švajčiarsko vedie rebríček konkurencieschopnosti vrátane inovácie a technologickej pripravenosti (Schwab 2012, s. 11). 


\section{Záver}

Slovensko sa nachádza na 23. mieste ako posledné zo skupiny moderate innovators v rámci EU27. Ako vyplynulo z výskumu GEM, z ktorého sme pri analyzovaní inovatívnej orientácie Slovenska prvotne vychádzali, inovatívnost' slovenských podnikatel'ov sa skúmala z pohl'adu 2 chápaní: (1) inovatívnost' podnikatel'ov z hl'adiska ponúkaných výrobkov alebo služieb a (2) inovatívnost' podnikatel'ov $\mathrm{z}$ hl'adiska využívanej technológie. Kým $\mathrm{v}$ inovatívnosti v podobe absorbovania najnovších technológií počiatoční aj etablovaní podnikatelia na Slovensku vykazujú vel'mi pozitívne hodnoty, čo sa týka uvádzania produktov na trh, ktoré ich zákazníci vnímajú ako nové, a pri ktorých zároveň neexistuje vel'a konkurentov, už v medzinárodnom porovnaní výrazne zaostávajú. $Z$ toho vyplýva záver, že tak počiatoční ako i etablovaní podnikatelia na Slovensku vo všeobecnosti skôr inovácie pasívne prijímajú, než by mali snahu ich sami na trh aktívne prinášat'.

Transfer vedy a výskumu sa na Slovensku vyznačuje najhorším stavom ako i výrazným zaostávaním. Najhoršia situácia je v dimenziách dotácií na získanie nových technológií pre nové a rastúce firmy a efektivity podpory vedecko-technickej základne na vytváranie venture podnikov založených na novej technológii na svetovej úrovni v aspoň jednej technologickej oblasti.

Slovensko svoj hospodársky rast postavilo na priamych zahraničných investíciách. Lákadlom pre investorov má byt' kvalifikovaná a stále lacná pracovná sila, cena práce je v porovnaní s priemerom OECD (100) na úrovni 46, pričom v Nemecku je to 148. Už na začiatku tohto procesu sa hovorilo o tom, že nastane čas, ked' sa budú investori presúvat' do iných krajín s ešte lacnejšou pracovnou silou a s väčšou ochotou vlád poskytovat' dotácie a daňové úl'avy. Hospodársky rozvoj nemá byt' totiž postavený na lacnej pracovnej sile, čo si uvedomuje i súčasná vláda vo svojom programe. Je čas zapojit' domáce vedecko-výskumné základne a domáce malé a stredné podniky a dat' tak konečne „zelenú“ inovačnému duchu. Nie je totiž možné viac tolerovat' praktiky, akými sme boli v tomto roku vystavení od Samsungu a US Steel Košice. Situácia je o to viac kritická, že vlastníctvo majetku typu oceliarne nemá len hospodársky, ale aj politický kontext, navyše, ide o silný vplyv a dopad v určitých regiónoch, ale aj prípadné obmedzenia konkurenčných výrob (Luby, Š., Chodák, I. 2012, s. 49).

Odpoved'ou na otázku, prečo dosahuje Slovensko v oblasti inovácií tak slabé výsledky, môžu byt' i závery z okrúhleho stola zo dňa 17.3.2011 v rámci projektu „Podpora inovácií v slovenských MSP“, ktorý organizovala Národná agentúra pre rozvoj malého a stredného podnikania za účasti predstavitel'ov Autoklastra, Eximbanky, SAV a viacerých realizovaných projektov: (1) Prílev priamych zahraničných investícií sa dostatočne neprejavuje na zvýšení investícií do inovácií vedy a výskumu, ale aj voblasti získavania vedeckovýskumných poznatkov a ich následnej aplikácie v praxi, ako i v oblasti organizačných inovácií. (2) Slovenské MSP sa vyznačujú slabou inovačnou schopnost'ou a to nielen $\mathrm{v}$ oblasti investovania do vedy a výskumu, ale aj $\mathrm{v}$ oblasti získavania vedeckovýskumných poznatkov a ich následnej aplikácie v praxi, ako aj v oblasti organizačných inovácií. Tu sa argumentuje aj tým, že podniky si zatial' zabezpečujú svoje zisky využívaním lacnej pracovnej sily tak, ako sme to už uvádzali vyššie. (3) Ponuka rizikových fondov je obmedzená. Väčšina MSP nemá ochotu pripustit' do vlastníckej štruktúry cudzí subjekt a ich očakávania ohl'adne výšky pomoci sú prehnané. Rizikový kapitál sa v prevažnej miere prezentuje formou pôžičiek, takže ako pasívny investor. (4) Inkubátory sú na Slovensku jednou z najstarších podôb podpory inovácií. Vel'ká väčšina firiem v inkubátoroch sú inovačne neaktívne podniky, ktoré do inkubátorov zlákal hlavne nízky nájom.

MSP slabo využívajú fondy ako CIP, 7. RP, ŠF idú do sféry nízkych technológií. Môžeme konštatovat', že v SR máme nedostatok inovačnej motivácie výskumníkov, nedostatok personálu v oblasti technologických inovácií, nedostatok zdrojov rizikového kapitálu. Pritom investori očakávajú podnikatel'ské plány s krátkym horizontom, 10 násobný zisk, chcú mat' zhodnotenú vel'kost' trhu a osobitne neveria univerzitám. Akademická sféra ponúka vel'mi málo patentov, nemá znalosti o inovačnom procese a nie je pripravená na inovačný neúspech, ktorý je štatisticky dost' vel'ký. 
V prvom rade je potrebné, aby efektívnejšie fungoval systém vedy, čo predpokladá lepšie dotácie pre vedu a výskum; ciel' $3 \%$ HDP do vedy a výskumu platí totiž pre všetky krajiny EU 27. Zároveň je potrebné ozdravit' grantový systém (odstránit' byrokraciu hlavne pri získavaní prostriedkov zo štrukturálnych fondov), zabraňovat' korupcii pri pridel'ovaní vel'kých projektov najmä zo štrukturálnych fondov (zodpovednou kontrolou vel'kých finančných tokov vedeckou obcou), prehodnotit' zámer transformácie APVV, lepšie zapojenie SAV do doktorandského štúdia. Ďalšou požiadavkou je fungovanie inovačného systému, čo je možné zvýšením záujmu o patentovanie, zvýšením kvality publikačných výstupov (v časopisoch s vel'kým impaktom), v ére vysokej špecializácie treba na technologický transfer vytvorit' premyslený systém (inovácie sa nevyriešia iniciatívou vedeckých pracovníkov alebo len samotných výrobcov), zdroje rizikového kapitálu spolu so subvencovaním a etablovat' systém vzdelávania pre inovátorov. Je kl'účové, aby mladí l’udia boli na vysokých školách vychovávaní ku kreativite, inovatívnosti a väčšej podnikavosti.

\section{Literatúra}

[1] ASHEIM, B. T., ISAKSEN, A. Location, Agglomeration and Innovation: Towards Regional Innovation Systems in Norway. European Planning Studies, Volume 5, 1997, No 3, pp 299 330. DOI: 10.1080/09654319708720402.

[2] BAUMOL, W. J. The Free-Market Innovation Machine. Princeton University Press, 2002.

[3] BURRONE, E., Jaiya, G. S. Intellectual Property Rights and Innovation in Small and Mediumsized Enterprises. Geneva: WIPO (World Intellectual Property Organisation).

[4] DVOŘÁK, J. a kol. Management inovací. 1. vyd. Praha: Vysoká škola manažerské informatiky a ekonomiky, 2006, 246 s. ISBN 80-86847-18-7.

[5] European Commission. Innovation Union Scoreboard 2011. Belgium: EC. ISBN 978-92-7923174-2. Dostupné z: $<$ http://ec.europa.eu/enterprise/policies/innovation/files/ius-2011_en.pdf $>$.

[6] European Commission. Green Paper on Innovation. Belgium: EC, December 2005. Dostupné z: $<\mathrm{http}$ //europa.eu/documents/comm/green_papers/pdf/com95_688_en.pdf $>$.

[7] KEKLIK, M. Schumpeter, Innovation an Growth. Burlington, USA: Ashgate Publ. Comp., 2003. ISBN 754618892.

[8] LUBY, Š., Chodák, I. Inovácie a technologický transfer v SR, osobitne v SAV. Čiastková štúdia vypracovaná v rámci riešenia programu Centra excelentnosti SAV - CESTA. Bratislava: Prognostický ústav SAV, november 2012.

[9] MICHIE, J. Introduction: The Internalization of the Innovation Process. International Journal of the Economics of Business, Vol. 5, No 3, pp 261 - 277. DOI: 10.1080/13571519884387.

[10] Ministerstvo financií SR. Správa o poskytnutej štátnej pomoci SR za rok 2008, máj 2009.

[11] Ministerstvo hospodárstva SR. Návrh inovačnej politiky na roky 2011 - 2013 v pôsobnosti Ministerstva hospodárstva SR. Bratislava: MH SR, 2011. Dostupné z: $<\mathrm{http}$ ://www.rokovania.sk/Rokovanie.aspx/BodRokovaniaDetail?idMaterial=19611>.

[12] OECD. Innovation in science, technology and industry. Oslo manual: Guidelines for Collecting and Interpreting Innovation Data, 3rd Edition, 2005.

[13]PILKOVÁ, A. a kol. Podnikanie na Slovensku: vysoká aktivita, nizke zdroje ašpirácie. GEM 2011. Bratislava: FM UK v Bratislave, 2012. ISBN 978-80-223-2823-4.

[14] ROTHWELL, R., GARDINER, P. Invention, Innovation, Re-innovation and the Role of the User. Technovation, 3, 1985, 176 - 186. DOI: 10.1016/0166-4972(85)90012-4.

[15] SCHUMPETER, J. A. Capitalism, Socialism and Democracy. New York: Harper and Row, 1942.

[16] SCHWAB, K. The Global Competitiveness Report 2012-2013. Geneva: WEF, 2012. ISBN 13: 978-92-95044-35-7. Dostupné z: <http://weforum.org/gcr>.

[17] VALENTA, F. Tvưrči aktivita - inovace - efekty. Praha: Svoboda, 1969. ISBN 25-093-69.

[18] VALENTA, F. Inovace v manažerské praxi. Praha: Velryba, 2001. ISBN 80-85860-11-2.

[19]Zákon č. 172/2005 Z. z. o organizácii štátnej podpory výskumu a vývoja v znení neskorších predpisov

Príspevok bol spracovaný v rámci projektu VEGA 1/0381/13 Hodnotenie inovačného potenciálu podnikatel'skej siete v ranných etapách jej formovania a projektu AKADÉMIE STING Podpora inovácii v „spin off“ a „start up“ firmách. 